\title{
THE SUBJECT MATTER OF COPYRIGHT
}

The constitutional basis for national copyright legislation is in Article I, Section 8, "The Congress shall have power: to promote the progress of science and useful arts, by securing for limited times to authors and inventors the exclusive right to their respective writings and discoveries."

Section 4 of the Copyright Act of March 4, 1909, provides, "That the works for which copyright may be secured under this act shall include all the writings of an author."

This is a wide and a sensible departure from all earlier statutes, which, by enumerating the various things which might be copyrighted, endangered liberal construction. Under the present act there is no limitation in the statute of the subject matter of copyright, except that imposed upon Congress by the constitutional grant of power.

Copyright protection, therefore, extends to all the writings of an author which promote the progress of science and useful arts.

This involves the consideration of three questions: (a) What is a writing? (b) What is an author? (c) What will promote the progress of science and useful arts?

\section{What is a Writing?}

"A writing," said Mr. Justice Miller, includes "all forms of writing, printing, engraving, etching, etc., by which the ideas in the mind of the author are given visible expression."

The case in which this language was used arose under the Copyright Act of July 18, 1874, and involved the validity of the copyright of one of Sarony's photographs of Oscar . Wilde. It was argued that since photographs were not haustive.

The citation of authorities is intended to be suggestive rather than ex-

${ }_{1}^{1}$ The proceeding was brought in 1882 during Wilde's lecture tour in this country, when his vogue was enormous though based almost entirely on impudence, long hair and knee breeches, a volume of poems and some pronounced opinions on art. The reporter of the Supreme Court begins his statement of the case thus: "This was a suit for an infringement of a copyright in a photograph of one Oscar Wilde," perhaps as a dissent from Wilde's well known and often expressed opinion of himself. See Newton, Amenities of Book Collecting, Boston, The Atlantic Monthly Press, 1918, Chapter XII. 
mentioned in the act as copyrightable subject matter, they were excluded from its scope, and further that a photograph was not a writing. ${ }^{2}$

The court, after commenting on the inclusion of maps and charts in the copyright acts of 1790 and 1802 , as giving a construction to the language of the constitution by men who were contemporary with it, many of whom were members of the convention which formed it, (Mr. Justice Miller) said:

"These statutes certainly answer the objection that books only, or writing in the limited sense of a book and its author, are within the constitutional provision."

$* \quad * \quad * \quad * \quad * * * * \quad * \quad *$

"We entertain no doubt that the Constitution is broad enough to cover an act authorizing copyright of photographs so far as they are representatives of original intellectual conceptions of the author."

"The third finding of facts says, in regard to the photograph in question, that it is a 'useful, new, harmonious, characteristic, and graceful picture, and that plaintiff made the same . . . entirely from his own original mental conception, to which he gave visible form by posing the said Oscar Wilde in front of the camera, selecting and arranging the costume, draperies, and other various accessories in said photograph, arranging the subject so as to present graceful outlines, arranging and disposing the light and shade, suggesting and evoking the desired expression, and from such disposition, arrangement, or representation, made entirely by plaintiff, he produced the picture in suit.'

"These findings, we think, show this photograph to be an original work of art, the product of plaintiff's intellectual invention, of which plaintiff is the author, and of a class of inventions for which the Constitution intended that Congress should secure to him the exclusive right to use, publish and sell, as it has done by section 4952 of the Revised Statutes."

${ }^{2}$ Burrow-Giles Lithographic Co. v. Satony, IrI U. S. 53. 
On the authority of the Sarony case it has been held that writings include maps and charts, designs, engravings, etchings, cuts and prints, ${ }^{3}$ photographs, ${ }^{4}$ motion picture films, ${ }^{5}$ musical compositions, ${ }^{6}$ lithographs. ${ }^{7}$

To constitute a writing, however, there must be something more than a mental conception not reduced to tangible form. The law does not deal with abstractions. A plan or scheme is not a writing and therefore is not copyrightable. This is illustrated by such cases as Baker v. Seldens where the plaintiff's book was a treatise on a system of bookkeeping illustrated by specimen account book pages consisting of ruled lines and headings showing the system and how it was to be used in practice. The defendant used account books based on substantially the same plan. There was no copying of the plaintiff's explanatory matter. It was contended by the plaintiff that the defendant infringed its copyright. It was held that the copyright did not embrace the method described and defendant did not infringe, Mr. Justice Bradley saying:

"The description of the art in a book, though entitled to the benefit of copyright, lays no foundation for an exclusive claim to the art itself. The object of the one is explanation; the object of the other is use. The former may be secured by copyright. The latter can only be secured, if it can be secured at all, by letters patent."

In Perris v. Hexamer, ${ }^{9}$ the plaintiffs were owners of a copyright in a series of maps of New York City useful to those in the fire insurance business. The maps showed each house and building and the classes as shown by different coloring and characters. The maps were made after careful survey and were so marked by arbitrary signs explained by a key that an insurer could see at a glance what

3 Burrow-Giles Lithographic Co. v. Sarony, IIr U. S. 53, 57.

- Burrow-Giles Lithographic Co. v. Sarony, III U. S. 53; Nottage v. Jackson, II Q. B. D. 627; Falk v. Brett Lithographing Co., 48 Fed. 678; Falk v. Donaldson, 57 Fed. 32; Falk v. City Item Printing Co., 79 Fed. $32 \mathrm{I}$. 265.

5 American Mutoscope \& Biograph Co. v. Edison Mfg. Co., 137 Fed. 262,

- White-Smith Music Pub. Co. v. Apollo Co., I39 Fed. 427, 430.

T Bleistein v. Donaldson Lithographing Co., I88 U. S. 239, 242, 249.

8 ror U. S. 99.

$\circ 99$ U. S. 675 . 
were the character and occupancy of any particular building or neighborhood necessary for his information in taking risks. The defendant made the necessary survey and published a similar series of maps of Philadelphia, using substantially the same key and coloring. It was held that there was no infringement.

In Griggs v. Perrin ${ }^{10}$, it was held that the copyright of a book describing a new system of shorthand, does not protect the system apart from the language by which it is explained, Judge Coxe saying:

"The copyright book is sacred but not the subject of which it treats. If the defendants have described the complainant's system they have not offended against the copyright law. If they have copied complainant's book they have offended against the law."

The rule is the same at common law. In the absence of special circumstances such as fraud or breach of contract, express or implied, one whose plan, scheme or idea, as distinguished from his unpublished manuscript, is appropriated, has no redress.

In one case often cited, plaintiff devised a system of advertising which was useful to insurance companies. This he communicated to the defendant as an inducement to his employment. The defendant appropriated the system and did not employ the plaintiff. Plaintiff sued to recover as if the defendant had used his property. It was held that the complainant did not state a cause of action.11

${ }^{10} 49$ Fed. r5. So also Burnell v. Chown, 69 Fed. 993, where complainant devised a system of collecting, classifying and publishing credit ratings with a key. Defendant used the same system in a territory different from that covered by plaintiff's publication. Judge Ricks:

"The most that can be claimed on behalf of the plaintiff is that the defendant has appropriated his scheme, device, conception and idea for gathering and imparting this particular information $*_{*}$ admitting that they have gathered this information and seek to impart it upon the same plan which the plaintiff has conceived and originated, that conception is not a matter which can be protected either by the copyright law or the common law."

See also: Amberg File \& Index Co. v. Shea Smith \& Co., 82 Fed. 314; Clayton v. Stone, 2 Paine 382; F. C. 2872; Burke v. Johnson, I46 Fed. 209.

11 Bristol v. Equitable Life Assn. Soc., 5 N. Y. S. I3I; I32 N. Y. 364 ; 30 N. E. 506. 
In another instance ${ }^{12}$ the complainant studied the white lead industry and formulated a plan for combining a number of companies and procured options or negotiated for their purchase, he then laid his plan before Thomas F. Ryan seeking his co-operation, agreeing to contribute if necessary $\$ 200,000$ if Ryan would join him, and also put up enough money to see it through. Ryan expressed a willingness to join, if an examination of the plan and papers by his counsel and experts confirmed the complainant's statements to him. Ryan, however, availed himself of the information the complainant had furnished and independently of him organized a company, got control of the industry, and made a large profit. Complainant sued to compel him to account. In dismissing the bill, Stevens, Vice Chancellor, said:

"Now, it has never been held, so far as I am aware, that mere ideas are capable of legal ownership and protection. I am therefore of the opinion that complainant has no property right in his plan regarded as an idea. Having no property right he has no right to an account."

Trade marks, not being writings of authors, for the same reason are not protectable under the copyright laws, and an act based on the constitutional provisions concerning authors and inventors was declared unconstitutional. ${ }^{13}$

A dance, telling no story, and conveying to the spectator no other idea than that a "comely woman is illustrating the poetry of motion in a singularly graceful fashion" 14

12 Haskins v. Ryan, 7I N. J. Eq. 575, 64 At. 436. The same rule applies in the case of inventions. Fowler v. City of New York, 121 Fed.-747; $58 \mathrm{C}$. C. A. II3; Coxe, C. J., (748):

"It is manifest that no mere abstraction, no idea however brilliant can be the subject of a patent irrespective of the means designed to give it effect."

See also: Ex parte Moeser C. D. (1905) 346, 118 O. G. 590; Ex parte Meinhardt C. D. (1907) 237, 238, 129 O. G. 3503; Burr v. Duryee, I Wall. 53I, 570; Westinghouse v. Borden, 170 U. S. 537; Fuller v. Yentzer, 94 U. S. 288; Bradford v. Expanded Metal Co., I46 Fed. 984.

${ }_{13}$ Trade Mark Cases, 100 U. S. 82, 94 .

14 In Fuller v. Bemis, 50 Fed. 926, the serpentine dance by Marie Louise Fuller, better known as Loie Fuller, was involved. This dance was in three tableaux and is described in great detail in the report. It was alleged to have been copyrighted and the bill averred that it was a dramatic composition and was being presented at Madison Square Theatre at New York with great success. The infringement complained of was the production by the defendant of Miss Fuller's dance with merely colorable alterations. Judge Lacombe held that the complainant's performance was not a dramatic composition. "It is 
is not a writing and has been held not copyrightable subject matter. So it has been held that a performance consisting of songs by an actress dressed to impersonate other singers, prefaced by a short and commonplace dialogue, with moving pictures during the intervals when the performer is changing costumes, is not copyrightable, because not a writing. ${ }^{15}$

A similar judicial fate met the tank of real water in the "Tank Drama." In In the fourth act of their play, "Donna Bianca" or "Brought to Light," the plaintiffs set in the stage a real tank three feet square and seven feet deep filled with real water, "the elaboration," said Judge Lacombe, "of Mr. Vincent Crummles' dramatic conception of a real pump and wash tubs." 17 This water flowed through a trough from behind a battlemented wall at the rear of the stage, falling into a tank and running off underneath essential," he said, "to such a composition, that it should tell some story. The plot may be simple. It may be but a narrative or representation of a single transaction; but it must repeat or mimic some action, speech, emotion, passion or character, real or imaginary. And when it does it is the ideas thus expressed which become subject to copyright. An examination of the description of complainant's dance, as filed for copyright, shows that the end sought for and accomplished was solely the devising of a series of graceful movements, combined with an attractive arrangement of drapery, lights and shadows, telling no story, portraying no character, depicting no emotion. The merely mechanical movements by which effects are produced on the stage are not subjects of copyright where they convey no ideas whose arrangement makes up a dramatic composition. Surely, those described and practiced here convey, and were devised to convey, to the spectator no other idea than that a comely woman is illustrating the poetry of motion in a singularly graceful fashion. Such an idea may be pleasing, but it can hardly be called dramatic."

15 Barnes v. Miner, I22 Fed. 480 .

${ }_{16}$ Serrana et al v. Jefferson, 33 Fed. 347 ; compare Daly v. Palmer, 6 Blatch. 256, Fed. Cas. 3552; Daly v. Webster, 56 Fed. 483, 486; Daly v. Brady, 39 Fed. 265; 69 Fed. 285; 75 U. S. 148; Vernon v. Schubert, 220 Fed. 694 ; Eichel v. Marcin, 24I Fed. 404; Stevenson v. Harris, 238 Fed. 432; Chappell v. Fields, 210 Fed. 864; Bloom v. Nixon, I25 Fed. 977 ; Savage v. Hoffman, 159 Fed. 584.

${ }^{27}$ It will be recalled that Nicholas and Smike, on their way to Portsmouth, were overtaken by dusk twelve miles from their destination. They turned into an inn and there met $\mathrm{Mr}$. Crummles. After a bowl of punch, Mr. Crummles discoursed on theatrical matters, finally persuading Nicholas to join his company as actor and dramatic adapter.

"We'll have a new show-piece out directly," said the manager. "Let me see-peculiar resources of this establishment-new and splendid sceneryyou must manage to introduce a real pump and two washing tubs."

"Into the piece?" said Nicholas.

"Yes," replied the manager. "I bought 'em cheap at a sale the other. day; and they'll come in admirably. That's the London plan. Then look up some dresses and properties, and have a piece written to fit them. Most of the theatres keep an author on purpose." 
the stage. The water in this tank and trough represented a river. It was crossed by a bridge, upon which, after an angry dialogue between the hero and the villain of the the play, there ensued a struggle in which the villain fell through the bridge into the water below. The defendants were putting on at the Academy of Music in New York a play entitled "A Dark Secret." Here, too, there was placed upon or set into the stage a tank considerably larger than the plaintiffs' tank and trough, also filled with real water and intended to represent the river Thames. Into this tank the heroine of the play was thrown after appropriate dialogue. It was contended that the defendants infringed the copyright in the plaintiffs' play. "It is alleged," said Judge Lacombe, "that these immersion scenes in the two plays are prominent features and add greatly to their attractiveness." He continued: "There is nothing original in the incident thus represented on the stage. Heroes and heroines, as well as villains, of both sexes, have for a time whereof the memory of the theatre-goer runneth not to the contrary, been precipitated into conventional ponds, lakes, rivers, and seas. So frequent a catastrophe may fairly be regarded as the common property of all playwrights. The plaintiffs' contention is founded solely upon the circumstance that in their play the river into which the fall takes place is mimicked by a tank filled with real water, instead of by an apparatus constructed of cloth, canvas, or painted pasteboard. Such a mechanical contrivance, however, is not protected by a copyright of the play in which it is introduced. The decisions which extend the definition of 'dramatic composition' so as to include situations and 'scenic' effects, do not cover the mere mechanical instrumentalities by which such effects or situations are produced."

\section{What is an Author?}

"An author," said Mr. Justice Miller, "is he to whom anything owes its origin; originator; maker; one who completes a work of science or literature," and accordingly 
held that a photographer who posed a subject, selected the costume, draperies and other various accessories so as to present graceful outlines, arranging and disposing the light and shade, and suggesting and evoking the desired expression, was an author and the photograph an original work of art.18 An author is, therefore, the creator of the particular work involved, bearing in mind always that the copyright covers not the subject matter but the personal reaction of the individual-the intellectual work bestowed-upon the subject matter. ${ }^{19}$ In the Sarony case it was not $a$ portrait of

18 Burrow-Giles Lithographing Co. v. Sarony, III U. S. 53, 60; Pagano v. Beseler, 234 Fed. 963; Gross v. Seligman, 212 Fed. 930; Bolles v. Outing Co., 175 U. S. 262. In Nottage v. Jackson, II Q. B. D. 627, the plaintiffs described themselves as the authors of the photograph which was pirated. It appeared that they had arranged with the captain of the Australian cricketers to take a photograph of the whole team in a group; and they sent one of the artists in their employ from London to some country town to do it.

The question in the case was whether the plaintiffs, who owned the establishment in London, where the photographs were made from the negative and were sold, and who had the negative taken by one of their men, were the authors, or the man who, for their benefit, took the negative. It was held that the latter was the author and the action failed because plaintiffs had described themselves as authors.

Brett, M. R., said in regard to who was the author: "The nearest I can come to, is that it is the person who effectively is as near as he can be the cause of the picture which is produced, that is, the person who has superintended the arrangement, who has actually formed the picture by putting the persons in position, and arranging the place where the people are to be-the man who is the effective cause of that."

Lord Justice Cotton said: "In my opinion 'author' involves originating, making, producing, as the inventive or master mind, the thing which is to be protected, whether it be a drawing, or a painting, or a photograph"; and Lord Justice Bowen says that photography is to be treated for the purposes of the act as an art, and the author is the man who really represents, creates, or gives effect to the idea, fancy or imagination.

The appeal of plaintiffs from the original judgment against them was accordingly dismissed.

Quoted and cited with approval in Burrow-Giles Lithographing Co. v. Sarony, III U. S. 53, 60.

19 Bleistein v. Donaldson Lithographic Co., I88 U. S. 239, 249. In holding that circus posters were the proper subject of copyright, Mr. Justice Holmes said:

"It is obvious also that the plaintiffs' case is not affected by the fact, if it be one, that the pictures represent actual groups-visible things. They seem from the testimony to have been composed from hints or descriptions, not from sight of a performance. But even if they had been drawn from the life, that fact would not deprive them of protection. The opposite proposition would mean that a portrait by Velasquez or Whistler was common property because others might try their hand on the same face. Others are free to copy the original. They are not free to copy the copy. Blunt v. Patten, 2 Paine 397, 400. See Kelly v. Morris, L. R. I Eq. 697; Morris v. Wright, L. R. 5 Ch. 279. The copy is the personal reaction of an individual upon nature. Personality always contains something unique. It expresses its singularity even 
Oscar Wilde which was protected, but the portrait which Sarony had created.

What is intellectual work upon common material naturally raises issues of great nicety. ${ }^{20}$

What promotes the progress of science and useful arts?

Given a writing of an author within the meaning of the constitution, whether or not it tends to promote the progress of science and useful arts is a source of some difficulty. The useful, however, is not limited to that which satisfies immediately bodily needs. ${ }^{21}$

Whether or not a work tends to promote the progress of science and useful arts depends, speaking generally, upon its merit and its morality.

\section{Merit.}

The degree of merit required by the judicial critics need not discourage any one from entering the field of literature or art. A very little is enough, and a work will be protected if it has any merit at all, however modest.

"It is difficult, almost impossible," says Burton in his Book Hunter, "to find a book from which something, either valuable or amusing, may not be found if the proper alembic be applied. I know books that are curious, and really amusing from their excessive badness. If you want to find precisely how a thing ought not to be said, you take one of them down and make it perform the service of the intoxiin handwriting and a very modest grade of art has in it something irreducible, which is one man's alone. That something he may copyright unless there is a restriction in the words of the act."

"The teachings of science and the rules and methods of useful art have their final end in application and use; and this application and use are what the public derive from the publication of a book which teaches them. But as embodied and taught in a literary composition or book, their essence consitss only in their statement. This alone is what is secured by the copyright." (Mr. Justice Bradley in Baker v. Selden, Ior U. S. 99, 104.)

${ }_{20}$ In a case over the alleged piracy of a stenographic report of speeches by Lord Rosebery, it was held that the shorthand reporter who took down and afterwards transcribed the speeches was the author of the transcript, that being his work. Walter v. Lane (1900) A. C. 539;83 L. T. (N. S.) 289 . This is further illustrated by the cases which hold that there is no copyright in the thing itself, e. g., news, but only in the form in which it is conveyed. Springfield v. Thame, 89 L. T. (N. S.) 242 . See in this connection International News Service v. Associated Press, 248 U. S. 215, XVII Michigan Law Review (April, 1919) p. 490 .

pi Mr. Justice Holmes in Bleistein v. Donaldson Lithographing Co., 188 U. S. 239,249 . 
cating Spartan slave. - . There are no better farces on or off the stage than when two or three congenial spirits ransack books of this kind, and compete with each other in taking fun out of them."

"Wherever I journey," says Owen Wister, "I read the time tables. I have been reading them for about fifty years. I prefer them to most of the novels you can pick from the newsboy's arms. To me our Official Railway Guide is the great American romance. The mere names of the stations-please meditate upon San Diego, Prairie du Chien, Fremont, New Orleans, New London, Sioux Citydisclose to him who knows how to read them, many pages of our history. Merely think of checking your trunk from Cicero to Bismarck!"

The most heterogeneous collection of what Elia calls "things in books' clothing" 22 have appeared in the reports

22 Lamb: Detached Thoughts on Books and Reading.

"To mind the inside of a book is to entertain one's self with the forced product of another man's brain. Now I think a man of quality and breeding may be much amused with the natural sprouts of his own."-Lord Foppington in the Relapse.

"An ingenious acquaintance of mine was so much struck with this bright sally of his Lordship that he has left off reading altogether, to the great improvement of his originality. At the hazard of losing some credit on this head, I must confess that I dedicate no inconsiderable portion of my time to other people's thoughts. I dream away my life in others' speculations. I love to lose myself in other men's minds. When I am not walking, I am reading; I cannot sit and think. Books think for me.

"I have no repugnances. Shaftsbury is not too genteel for me, nor Jonathan Wild too low. I can read anything which I call a book. There are things in that shape which I cannot allow for such.

"In this catalogue of books which are no books-biblia a-biblia-I reckon Court Calendars, Directories, Pocket Books, Draught Boards, bound and lettered on the back, Scientific Treatises, Almanacks, Statutes at Large; the works of Hume, Gibbon, Robertson, Beattie, Soame Jenyns, and generally, all those volumes which 'no gentleman's library should be without': the Histories of ' Flavius Josephus (that learned Jew), and Paley's Moral Philosophy. With these exceptions $I$ can read almost anything. I bless my stars for a taste so catholic, so unexcluding.

"I confess that it moves my spleen to see these things in books' clothing perched upon shelves, like false saints, usurpers of true shrines, intruders into the sanctuary, thrusting out the legitimate occupants. To reach down a wellbound semblance of a volume, and hope it some kind-hearted play-book, then, opening what 'seem it leaves,' to come bolt upon a withering Population Essay; to expect a Steele, or a Farquhar, and find-Adam Smith; to view a well arranged assortment of blockheaded Encyclopaedias (Anglicanas or Metropolitanas) set out in an array of russia or morocco, when a tithe of that good leather would comfortably clothe my shivering folios, would renovate Paracelsus himself, and enable old Raymund Lully to look like himself again in the world. I never see these imposters but I long to strip them, to warm my ragged veterans in their spoils." 
with counsel to contend their literary merit. Legal blanks, ${ }^{23}$ the arrangement of cases in a law report, ${ }^{24}$ credit ratings, ${ }^{25}$ while directories, guide books and the like seem more attractive to the pirate than literature. ${ }^{26}$ Catalogues have often been involved in litigation and from insufficient premises it has been sought to draw the conclusion that catalogues cannot be the subject matter of copyright.

The first catalogue case in point of time was Hotten v. Arthur ${ }^{27}$ which involved a catalogue of books. Complainant,

23 Brightley v. Littleton, 37 Fed. 103.

24 Callaghan v. Myers, 128 U. S. 617, 645 .

${ }^{25}$ Ladd v. Oxnard, 75 Fed. 703.

${ }^{26}$ Architectural Dictionary, Barfield v. Nicholson, 2 Sim. \& St. I; Spiers' School Dictionary, Spiers v. Brown, 6 W. R. 352; Swedish Dictionary, Chils v. Gronlund, 40 Fed. 145; Gazetteer of England and Wales, Lewis v. Fullerton, 2 Beav. 6; Hand Book of Switzerland, Murray v. Bogue, I Drew. 353; London Directory, Kelly v. Hooper, 4 Jur. 21, I Y. \& Coll. C. C. I97; Kelly v. Morris, L. R. I Eq. 697; Morris v. Ashbee, L. R. 7 Eq. 34; Morris v. Wright, L. R. 5 Ch. 279; Brighton Suburban Directory, Kelly v. Hodge, 29 L. T., N. S., 387 ; New York Directory, Trow Co. v. U. S. Directory Co., I22 Fed. I91; Chicago Directory, Chicago Dollar Directory Co. v. Chicago Directory Co., 66 Fed. 977 ; Chicago Directory Co. v. U. S. Co., I2I Fed. I9I; Society Directory, List Publishing Co. v. Keller, 30 Fed. 772; Social Reg. Assn. v. Murphy, I28 Fed. II6; Trades Directory, Lamb v. Evans (1892) 3 Ch. 681, C. A. (I893) I Ch., 218; East India Calendar and Directory, Mathewson v. Stockdale, I2 Ves. Jr. 270; Gardeners' Year Book Almanac \& Directory, Hogg v. Scott, L. R. I8 Eq. 444; Court Calendar, Longman v. Winchester, 16 Ves. 268; Almanac, Company of Stationers v. Seymour, Skinner 234; Psalm Book, Company of Stationers v. Wright, Skin. Nev. 234; Chronology, Trusler v. Murray, I East. 363 n.; List of Hounds, Cox v. Land \& Water Journal, L. R. 9 Eq. 324 ; Quotations from Stock Exchange, Exchange Telegraph Co. v. Gregory, 73 L. T. I20 (I896), I Q. B. I47; List of Bills of Sale, Trade Auxiliary Co. v. Middleborough Assn., L. R. 40 Ch. D. 425; Index to Abstracts, Banker v. Caldwell, 3 Minn. 94; Clyde Bill of Entry and Shipping List, McLean v. Moody, 20 Sess. Cas., 2 Ser. II54; Wolford v. Johnson, Id., r160 n.; Compilation in regard to Bankruptcy Register, Trade Auxiliary Co. v. Irish Trade Agency, Irish L. T. 37; Directory, William v. Smythe, IIo Fed. 96I; Newspaper Telegrams, Wilson v. Rawcroft, 4 A. L. J. R. 57; Wilson v. Luke, I V. L. R. (E), I27; Mineral Statistics of United Kingdom, Scott v. Stanford, L. R. 3 Eq. 718; Notes to Scott's Border Minstrelsy, Black v. Murray, 9 S. S. C., 3 Ser. 34 ; Birthday Scripture Text Book, Mack v. Potter, L. R. I4 Eq. $43 \mathrm{I}$; Flora's Interpreter, (Language of Flowers), Webb v. Powers, F. C. I7323, 2 W. \& M., 497; The Art of Defense with the Broadsword, Raworth v. Wilkes, I Camp. 94; Birds Eye View of Seat of War, Standard v. Lee, $6 \mathrm{~L}$. R. Ch. 346; Collection of Songs, Canadian Music Pub. Assn. v. Winnifrith Bros., I5 O. R. 164; Collection of Poems, Campbell v. Scott, II Sim. 3I; Biographical Sketches, Gemmild v. Garland, I4 Sup. Ct. Rep., 32I, I2 Ont. Rep. 139; Correspondence of Washington, Folsom v. Marsh, F. C., 4904; Childs A. B. C., Childs Ladder Primers, Lennie v. Pillars, S. S. C. 2 Ser. Vol. 5 P., 466; Adams Latin Grammar, Gray v. Russell, F. C., 5728; Covills English Grammar, Greene v. Bishop, F. C., 5763; Graded Lessons in English, Reed v. Holliday, I9 Fed. 325; Guide to Science, Jarrould v. Houlston, 3 H. \& J. 708; System of Dress Cutting, Harburg v. Dunisday, 1o V. L. R. (E) I72; see Copinger on Copyright, 40, 44, 64; Drone on Copyright, 159, 160; Story's Equity, Sec. 941.

${ }^{27}$ (1863) I H. \& M. 603; 7I Fuel Reprint 264. 
a bookseller, issued a catalogue which was not a mere dry list of names of books and their prices, but contained a short account of their history or notices of their contents and anecdotes. Defendant, a rival bookseller, without license copied parts of the complainant's catalogue. ViceChancellor Page Wood directed an injunction.

In Cobbett v. Woodward ${ }^{28}$ Lord Romilly refused to follow Vice-Chancellor Page Wood and refused to protect a housefurnishing guide.

In Grace v. Nerwman ${ }^{29}$ Vice-Chancellor Hall followed Hotten v. Arthur and protected a stonemason's catalogue containing illustrations of tombstones.

Cobbett v. Woodrward was, however, in 1882, expressly overruled in Maple v. Junior Army \& Navy Stores, ${ }^{30}$ Jessel, M. R., saying:

"I doubt whether Cobbett v. Woodward is correct. Even on Lord Romilly's statement a part was entitled to copyright, and that would protect the whole. If there is copyright in any part it protects all the original matter. Illustrations, for this purpose, are part of the text."

"I cannot see why we should so construe the Act as to protect people who take other people's pictures, a proceeding which does not at first sight appear to be particularly honest. If the court can so construe the Act as to prevent dishonesty, it ought to do so. That would be my opinion if there was nothing else to be considered."

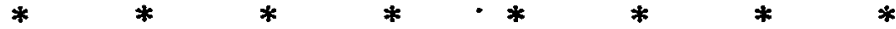

In $1898^{31}$ the rule was considerably enlarged. The subject matter was a druggist's catalogue which had been copied by a competitor.

"But what has -been done in this case," said Mr. Justice North, "is to leave the neighbor who was the first to prepare a catalogue to bear all the expense and trouble of doing it, and to

${ }^{28}$ (1872) L. R. 14 Eq. 407; 27 L. T. (N. S.) 260.

29 (1875) L. R. I9 Eq. 623 .

${ }^{30}$ L. R. 2I Ch. D. $369 ; 47$ L. T. (N. S.) 589.

${ }^{31}$ Callis v. Cater, 78 L. T. (N. S.) 6r3. The question is no longer debatable in England and catalogues are a recognized subject of copyright protection. Davis v. Benjamin (1906) 2 Ch. 491; 95 L. T. (N. S.) 67r; Weathersby v. International Horse Agency \& Ex., Ch. (I9I0) 2 Ch. 297; 102 L. T. (N. S.) 856; Cooper v. Stephens (1895) I Ch. 567; 7 L. T. (N. S.) 390; Marshall v. Bull, 85 L. T. (N. S.) 77,8 I. 
set to work without trouble or expense to take a copy of that catalogue and have one printed from it. The man who acts thus is simply using his neighbor's expense and labor for his own advantage. $\mathrm{He}$ is what is called pirating his neighbor's book. The question is whether that is a thing he has a right to do."

"I think I am bound by these cases. They seem to me to apply here, and I must hold that as there is copyright in a directory there is copyright in a list of articles prepared by a person who deals in them, and advertises them as articles which he sells, and in which he names the prices at which he will sell. That, it seems to me, is a case in which the law is settled, and applies to a catalogue such as this."

* $\quad * \quad * \quad * \quad * \quad * \quad * \quad * \quad * \quad * \quad * \quad *$

The Supreme Court of the United States has in effect adopted the liberal view which prevails in England, ${ }^{32}$ and is inclined to make the defendant himself the judge of the merit of the plaintiff's composition, and to hold that anything which is good enough for the defendant to steal is good enough for the law to protect.

The authority of Mott Iron Works v. Clow, ${ }^{33}$ where it was. held that a catalogue of plumber's supplies was not a proper subject for copyright is much weakened by these decisions and it probably must be considered overruled.

If any one doubts that catalogues ought to be copyrightable he should read Newton's chapter on "Old Catalogues \& New Prices" 34 and Eugene Field's Chapter XVI

32 Bleistein v. Donaldson, 188 U. S. 239.

3382 Fed. 316. Da Prato Statuary Co. v. Guiliani Statuary Co., I89 Fed. 90. Copyright in a catalogue of Ecclesiastical statuary was held valid. Other courts have ruled similarly in White v. Shapiro, 227 Fed. 957; National Cloak \& Suit Co. v. Kaufman, I89 Fed. 215; Golden Rule Co. v. B. V. D. Co., 242 Fed. 929. See also for the law of England concerning such trade compilations: Lamb v. Evans, 68 L. T. (N. S.) I3I, I34. Bowen, L. J. Kay, L. J. (I36); Scott v. Stanford, 16 L. T. (N. S.) 5 I. Vice Chancellor Wood (53); Exchange Telegraph Company v. Gregory, 74 L. T. (N. S.) 83; Leslie v. Young (House of Lords) (1894) A. C. 335; Ager v. Peninsular and Oriental System Steam Navigation Company, L. R. $26 \mathrm{Ch}$. Div. 637, where complainant's book was a telegraph code; Church v. Linton, 25 Ontario Rep. I3I; a blank form for stammerers. In Hall v. Whittington, I8 Vict. L. R. 525, the publication consisted of information collected by searches made at the public registry offices, and presented in the form of lists of bills of sale and notices of intention to file them, stock mortgages and renewals, liens on crops or wool, contracts, insolvencies, dissolutions of partnership, sheriff's sales, applications for probate, dividends and other particulars. Held copyrightable; Stone v. White, 8 N. Z. L. R. 58; a railway time table. Press, I918.

Newton-The Amenities of Book Collecting-Boston Atlantic Monthly 
which is entitled "The Malady called Catalogitis" in the "Love Affairs of a Bibliomaniac." 35

The refusal to protect catalogues and the like, manifested by some judges, is likely due to the fact that unconsciously it is natural to feel that such things. are not literature, indeed, the courts have often said so, but copyrightable literature need not be a work of genius. Useful books are seldom inspired. No one wants an inspired law book, a transfigured directory or an idealized dictionary. Accuracy, care, discrimination, are the qualities needed to produce such works, not the divine fire.

To be the proper subject matter of copyright, therefore, there need only be, somewhere in the work, an exercise of the creative powers of the mind, and if it have some value either as conveying information that is new or old information in such form as required in its preparation judgment, selection, or intellectual effort, the copyright law protects it.

In speaking of a book which he called a well designed stimulant to the special faculties which are required to meet a particular emergency-the successful passing of examinations, Lord Justice Collins said:

"As I have already said, though the work does not perhaps range in the highest scale of literature, it has shown a very considerable amount of skill, and certainly the adaptation of means to an end; for, whatever we think of the end, the means seem so admirably adapted to the end that the defendant, Mr. Marshall, pays the highest compliment one man can pay to another-namely, the compliment of imitation. The sources from which these works were drawn were common. It was open to anybody to compile an edition of 'As You Like It,' and open to him to go to

35 "Bring in the candles, good servitor, and range tham at my bed's head; sweet avocation awaits me, for here I have a goodly parcel of catalogues with which to commune. They are messages from Methuen, Sotheran, Libbie, Irvine, Hutt, Davie, Baer, Crawford, Bangs, McClurg, Matthews, Francis, Bouton, Scribner, Benjamin, and a score of other friends in every part of Christendom; they deserve and they shall have my respectful-nay, my enthusiastic attention. Once more I shall seem to be in the old familiar shops where treasures abound and where patient delving bringeth rich rewards. Egad, what a spendthrift I shall be this night; pence, shillings, thalers, marks, francs, dollars, sovereigns - they are the same to me!

"Then, after I have comprehended all the treasures within reach, how sweet shall be my dreams of shelves overflowing with the wealth of which my fancy has possessed me." 
all the sources of criticism and to make selections from them. It was open to him to cull quotations from other books and to put them together as the author of the plaintiffs' book has done, and clearly that was subject matter of copyright for them. He has shown skill and industry and many higher qualities."

It was of course argued that quotations are the common property of everybody, and that the defendant ought not to be restrained from using those which were apt.

"That leaves out the whole merit," said the Master of the Rolls, "the felicity of the quotation; its adaptability to a particular end; its illustration of a particular characteristic. All those things enter into the choice of one quotation as apart from another. That is a process which may involve gifts both of knowledge and intelligence. The aptness of quotation does not depend on the particular page or number of lines in which it is found; and that is all you find if you obey a certain direction to go to a certain place and take it. It does not entitle you to annex the skill and judgment and taste which has dictated the selection." 36

When the merit claimed for work is dependent upon its humor the question is frequently difficult. What to a court of a serious turn of mind would appear to be trivial and useless might to another seem amusing, and if amusing, useful.37 A court, in order to determine the question of 469.

${ }^{36}$ Moffatt \& Paige Lim. v. George Gill \& Sons Lim., etc., 86 L. T. (N. S.)

${ }^{37}$ In Henderson v. Tompkins, 60 Fed. 758, the complainant was the proprietor of the Chicago Opera House, where he presented a dramatic composition entitled "Ali Baba" or "Morgiana and the Forty Thieves," of which he was the owner of the copyright. The bill of complaint, after beginning with the usual resonant allegations with which bills in equity are plentifully sprinkled even today, continued: "That a part of said dramatic composition was as follows: 'Cassim (scornfully): But Ali Baba's selection is certain. Nico: I know it. Arraby: How do you know? Hack: She had a dream last night. Caliph (coming down stage): I wonder if dreams come true." "And that the said dialogue was then immediately followed by a song entitled, "Quartette for Ali Baba: I Wonder if Dreams Come True," consisting of a number of verses of eight lines, in each of which the second, fourth and eighth lines consist of the refrain, "I wonder if dreams come true," and the chorus after each verse is as follows:

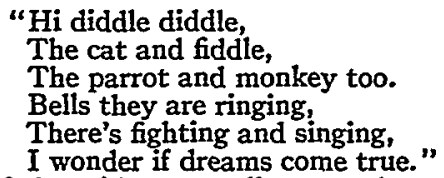

And that each of the said verses, all except the second, fourth and eighth lines aforesaid, were of a so-called "topical" nature (that is to say, relating to topics of current interest), and that the matter of the said topical lines was intended to be changed or varied from time to time to introduce allusions to new topics, the whole constituting what is known as the topical song, "I Wonder if Dreams Come True." 
copyrightability, must be at once a censor and a critic. Several judges have hesitated to assume the role. "If," said one of them who appreciated his difficult position, "judicial tribunals could lay down maxims by which to determine judicially that dramatic compositions claimed to be humorous, or to appeal to the sense of humor, are in this particular within or without the copyright act, they would by demonstration be in possession of rules which would enable them to be themselves at all times witty at their own option." 38 And, too, when judges try to answer the vexed question, "What is Art," complete uniformity of decision can hardly be expected. A safe rule has been laid down by the Supreme Court, when Mr. Justice Holmes remarked:

"It would be a dangerous undertaking for persons trained only to the law to constitute themselves final judges of the worth

It was then alleged "that the song with its introduction formed a substantial and valuable part of complainant's dramatic composition"; that defendant presented a spectacle at the Boston Theatre, Boston, and that " $a$ substantial and material and important portion consists of a dialogue between various characters in relation to having had a dream, the said dialogue terminating in a speech by one of said characters, as follows: 'I wonder if dreams come true, which said speech is immediately followed by a topical song of a number of verses of eight lines each, the second, fourth and eighth of which consist of the words or refrain, 'I Wonder if Dreams Come True'; that each of said verses is followed by the chorus of your orator's said song, and that the remainder of the lines in each verse are topical in character, and in substantial imitation of the said topical portions of your orator's said copyrighted song."

A demurrer was interposed and it was argued that the so-called dramatic composition was so titterly worthless and insignificant as to be unworthy of protection.

Judge Putnam overruled the demurrer (762), saying:

"The defendant alleges that the subject matter of this copyright does not tend to promote the progress of science and useful arts, and therefore is not within the scope of the power granted congress by the constitution. So far as this is a general proposition, aimed at all dramatic compositions of the character in question in the case at bar, it needs but little consideration. The court is not disposed to take the narrow view of the expression 'useful arts' propounded on either side of this case, nor does it seem necessary to determine whether the purpose announced in this paragraph of the Constitution directly or indirectly imits the powers of Congress, as claimed by the defendant and denied by the complainant. It is enough to say that whether we look only at the direct results of what is addressed to the taste, to the imagination, or the capacity of being amused, and the enjoyment which immediately follows therefrom, or whether we look further, and consider what is essential to keep the physical, moral and intellectual powers refreshed, all such have been regarded by the courts, ever since patents or copyrights were authorized by statute, as within the range of utility and the useful arts. Even when the intellect is strained to accomplish its greatest results, the standard prescription from Euclid may be useful, but an occasional one from the Book of Nonsense is not to be despised." ${ }^{38}$ Putnam, C. J., in Henderson v. Tompkins, 60 Fed. 758, 762. 
of pictorial illustrations, outside of the narrowest and most obvious limits. At the one extreme some works of genius would be sure to miss appreciation. Their very novelty would make them repulsive until the public had learned the new language in which their author spoke. It may be more than doubted, for instance, whether the etchings of Goya or the paintings of Manet would have been sure of protection when seen for the first time. At the other end copyright would be denied to pictures which appealed to a public less educated than the judge. Yet if they command the interest of any public they have a commercial value-it would be bold to say that they have not an aesthetic and educational value-and the taste of any public is not to be treated with contempt. It is an ultimate fact for the moment, whatever may be our hopes for a change." 39

When lay persons presume to pass on art they should be circumspect and recall Whistler's comment on the action of General Rush Hawkins, who was American Commissioner at the Paris Exposition, and, not appreciating Whistler's etchings, wrote him:

30 Mr. Justice Holmes, in Bleistein v. Donaldson Lithographing Co., I88 U. S. 239 (25I): In this case the lower courts had held that circus posters were not artistic works within the meaning of the copyright act and the language. quoted was used by Mr. Justice Holmes, speaking for the Supreme Court, in overruling this contention and reversing the decisions below. Among other authorities cited in this opinion is Ruskin's "Element of Drawing," which recalls the celebrated case of Whistler $v$. Ruskin, which is curiously relevant to this discussion. Whistler placed a price of 200 guineas on the Nocturne in Black and Gold-The Falling Rocket. Ruskin dissented from Whistler's notions of art, and in the course of a review in "Fors Clavigera," said:

"I have seen and heard much of cockney impudence before now, but never expected to hear a coxcomb ask 200 guineas for flinging a pot of paint into the public's face." picture:

A libel suit followed. In the course of his testimony Whistler defined a

"It is an arrangement of line, form and color first, and I make use of any incident of it which shall bring about a symmetrical result."

Rosetti was called as a witness and he was asked by the Attorney General, who represented Ruskin, concerning The Falling Rocket:

"Is it a gem?" "No."

"Is it an exquisite painting?" "No."

"Is it very beautiful?" "No."

"Is it a work of art?" "Yes, it is."

Burne-Jones was asked about the same picture:

"Now, take the Nocturne in Black and Gold-The Falling Rocketis that, in your opinion, a work of art?"

Burne-Jones: "No, I cannot say that it is. It is only one of a thousand failures that artists have made in their efforts to paint Night."

Other people, equally distinguished, testified that in their opinion the Nocturne in Black and Gold-The Falling Rocket-was not a work of art. The jury awarded one farthing damages, and the court declined to give costs to the successful plaintiff. The details of this interesting trial are to be found in the Pennells' Life of Whistler, Chapter 19, and in Whistler's "Gentle Art of Making Enemies." 
"Ten of your exhibits have not received the approval of the jury. Will you kindly remove them."

Whistler called and took them away, and afterwards said:

"The pretty embarrassment of General Hawkins on the occasion of my visit I myself liked, thinking it seemly and part of the good form of a West Point man who is taught that a drumhead court martial-and what else in the experience of this finished officer should so fit him for sitting in judgment upon picturesshould be presided at with grave and softened demeanor."

Chicago, Illinois.

Edward S. Rogers. 